University of Nebraska - Lincoln

DigitalCommons@University of Nebraska-Lincoln

1960

\title{
Classification and Evolutionary Relationships of The Sea Ducks
}

Paul A. Johnsgard

University of Nebraska-Lincoln, pajohnsgard@gmail.com

Follow this and additional works at: https://digitalcommons.unl.edu/biosciornithology

Part of the Ornithology Commons

Johnsgard, Paul A., "Classification and Evolutionary Relationships of The Sea Ducks" (1960). Papers in Ornithology. 70.

https://digitalcommons.unl.edu/biosciornithology/70

This Article is brought to you for free and open access by the Papers in the Biological Sciences at DigitalCommons@University of Nebraska - Lincoln. It has been accepted for inclusion in Papers in Ornithology by an authorized administrator of DigitalCommons@University of Nebraska - Lincoln. 


\title{
CLASSIFICATION AND EVOLUTIONARY RELATIONSHIPS OF THE SEA DUCKS
}

\author{
By PAUL A. JOHNSGARD
}

When Delacour and Mayr (1945) revised the classification of the Anatidae, one of their major innovations was the erection of the tribe Mergini, the members of which had in the past (Peters, 1931) been included in the subfamilies Nyrocinae (=Aythyinae) and Merginae. This separation of the true pochards (Netta and Aythya) from the other diving ducks and the merging of the merganser group into the same tribe with the goldeneyes (Bucephala) and other sea ducks has been accepted by most authorities and incorporated into recent classifications such as those of Kagelmann (1951) and Boetticher (1952), although it still is not accepted by the A.O.U. Check-list (1957). However, the eiders, which until 1945 had been included without exception with the scoters (Melanitta), goldeneyes and other diving ducks, were only provisionally placed in the Mergini, since Delacour and Mayr pointed out that the eiders' tracheal anatomy and the pattern of their downy young differed from those of the other members of the Mergini.

Delacour and Mayr characterized the tribe Mergini as follows: They are mainly sea dwellers and consume primarily animal food, which is usually obtained by diving. Their bills are strong and hooked but extremely variable in shape. Their wings are generally short, the flight heavy, and walking on land is done with some difficulty. Many species nest in crevices or hollows, but a few nest on the ground. Males of most species are brightly colored and have distinct "eclipse" plumages, but metallic coloration is generally restricted to the head region. Sexual maturity is not reached before the second or third year, and even when mature most species are not particularly noisy birds. Males of nearly all species have elaborate displays, and most species are northern in distribution. The downy young tend to be boldly patterned with dark gray and white, usually having a distinctive "capped" head appearance. Delacour and Mayr suggested that the tribe's closest relatives might be the perching ducks (Cairinini), because of the similarities of these tribes in nesting habits and the long, broad tails found in many species of both groups. However, evidence from hybridization (Johnsgard, 1960a) indicates that these tribes are not closely related, which is also suggested by the differences in the downy young as well as behavioral differences (Johnsgard, 1960b).

The first major criticism of this proposed arrangement came from Humphrey (MS, thesis Univ. Mich.), who studied the tracheal anatomy of nearly all the members of the tribe, the only exception being that of the extinct Labrador Duck (Camptorhynchus iabradorius). Humphrey found that the male tracheas of the included species fell broadly into two groups. In one of these, including all the eiders and the Harlequin Duck (Histrionicus histrionicus), the tracheas are relatively uniform in diameter throughout, and the tracheal bullae are completely ossified and rounded asymmetrically toward the left. Such a tracheal condition is also found in the shelducks and sheldgeese (Tadornini), dabbling ducks (Anatini), and perching ducks (Cairinini).

The rest of the tribe possesses tracheas which are more variable, but they tend to have tracheal tubes of varying diameters and tracheal bullae which are either rudimentary (scoters) or of rather complex shape and possessing membranaceous fenestrae (the rest of the tribe). Such a tracheal form is also found in the pochard group (Aythyini) and appears to be the highest degree of tracheal specialization in the entire Anatidae.

Humphrey (MS) concluded that the Mergini is actually composed of two "unrelated groups of birds, some members of which have independently evolved similar diving adaptations." 
Humphrey agreed that the mergansers (Mergus) are closely related to the goldeneye group, and he accepted the generic classification of Delacour and Mayr with the single exception of the Steller Eider (Polysticta stelleri), which Humphrey believed should be retained as a monotypic genus apart from the typical eiders (Somateria). Humphrey did not decide whether the Harlequin Duck belongs with the eider group, which it resembles in tracheal structure, or with the rest of the sea ducks, which it resembles in nearly every other respect. $\mathrm{He}$ also did not indicate in which group he believed the Labrador Duck to belong.

In 1958, however, Humphrey supported the view that the eiders should be placed in a separate tribe "Somateriini," adjacent to the dabbling ducks (Anatini). The following characteristics of the eiders were given in favor of this separation: (1) the Anaslike tracheal structure of male eiders, (2) the Anas-like plumage patterns of female eiders, (3) the pattern of the downy young of eiders, which differs from the other sea ducks, (4) the belief that (p.132) "eiders may take large percentages of plant foods while on the breeding grounds," (5) the use of the wings by eiders when diving and the leaving of them partly open when under water, as in most Anas species, and (6) the tendency of eiders to "tip-up" when feeding in shallow water. Delacour (1959) accepted Humphrey's proposals for the generic separation of the Steller Eider.

In defense of Delacour and Mayr's (1945) original classification, the opposing arguments should be mentioned here for each of Humphrey's points. The separation of the eiders on the basis of the trachea cannot be done without including the Harlequin Duck in the eider tribe, although on every other account it is more like the typical sea ducks. In addition, Wilson's (1829:370) description of the trachea of the Labrador Duck, not mentioned by Humphrey, suggests that it too has a bulla like those of the eiders, "bony, and round, puffing out from the left side," and a tracheal tube which is variable in diameter as in the other sea ducks and especially like those of scoters. The plumage of female eiders is admittedly Anas-like, as is the distinct speculum on the secondaries. However, this similarity in body plumage can in part be accounted for by the similarities of nesting habitats utilized by the two groups; thus similar selective pressures for disruptive coloration in females is operative. Yet the species which is presumably the closest relative of Anas, the Steller Eider, is actually more similar in plumage to females of the Labrador Duck, the scoters, and the Harlequin Duck, which latter also has a metallic speculum on the secondaries.

Although the young are certainly distinctive, downy eiders are not at all Anas-like, and indeed they are more like those of the scoters (especially Melanitta nigra) than any other group. There is little or no reason to believe that the eiders, which consume a higher proportion of animal food than many of the other sea ducks (Cottam, 1939), should suddenly switch to eating plant food during the breeding season when a high protein diet is essential for reproduction. This is certainly not true of eiders in captivity.

The use of the wings when diving is not a useful taxonomic criterion. Some species of Anas, mainly the larger species, normally do use their wings, whereas others, such as Anas capensis, rarely or never do so. That this is probably a function of the ratio between body mass and foot area is suggested by the fact that the large form of the Pintail ( $A$. acuta) normally uses its wings while diving whereas the much smaller Kerguelen Pintail dives without opening its wings. Myres (MS, thesis Univ. B.C.) mentions that among the sea ducks the eiders, scoters, Old-squaw (Clangula hyemalis) and Harlequin open their wings and spread the alula, whereas the Bucephala-Mergus group dives with the wings tightly closed. Juvenal Common Eiders also dive with their wings closed.

Finally, the fact that eiders often tip-up in shallow water is of no significance whatsoever. I have observed species representing every tribe of Anatinae tip-up in shallow 
water, including even the stiff-tail group (Oxyurini). Whether or not a species tips-up simply depends upon how deep the water is.

The second major investigation of the sea ducks has been that of Myres (MS, loc. cit.), which was entirely behavioral in scope. Myres was able to study 11 out of the 18 existing species and he obtained particularly useful and detailed information on the scoters and goldeneye-bufflehead groups. He did not, however, succeed in obtaining many first-hand observations on the genera Polysticta and Mergus. Myres' conclusions differ considerably from those of Humphrey. Myres found no evidence that the eiders are closely related to the Anatini. He states: "In female and pre-copulatory behavior characteristics, both Somateriini and Mergini are shown to be quite distinct from the Anatini. In female courtship behavior Somateria resembles some of the Aythyini and Melanitta." Myres found that female displays and displays associated with copulation are the only aspects of behavior sufficiently conservative to use in assessing generic and tribal affinities. In this respect the Old-squaw was found to be closely related to the scoters. The Bufflehead was found to be fairly distinct from the goldeneyes, possibly warranting generic separation from them, and also exhibiting some similarities with the scoters (Myres, 1959).

Myres did not observe a sufficient number of merganser species to compare them adequately with the goldeneye group, but he judged that they were probably closely related. Recent observations on the copulatory behavior of the Hooded Merganser (Mergus cucullatus) have proved the very close affinities between Mergus and Bucephala (Johnsgard, 1961). Myres (MS) states that in two behavioral respects, female "chin-lifting" and the long-soliciting prone posture before copulation, the eiders resemble the other sea ducks, but he indicated that these similarities might be the result of convergence. He concluded finally that "the relationship of the Somateriini to the Anatini is not indicated by their displays. The Mergini appears to be ancient and/or polyphyletic."

To summarize the situation, all investigators are in agreement that the BucephalaMergus assemblage is a valid one. This group has been separated by Boetticher (1952) and Kagelmann (1951) into an infra-tribal group, the "Mergeae," with the rest of the sea ducks being placed in the "Somatereae." Thus we have the following modern major arrangements of the sea ducks in'existence:

Delacour and
Mayr (1945)
MERGINI
Somateria
Camptorhynchus
Melanitta
Histrionicus
Clangula
Bucephala
Mergus

Humphrey (MS; 1958)
and Delacour (1959)
sOMATERIINI
Somateria
Polysticta
MERGINI
Melanitta
Camptorhynchus
Histrionicus
Clangula
Bucephala
Mergus

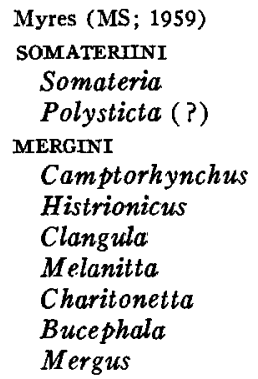

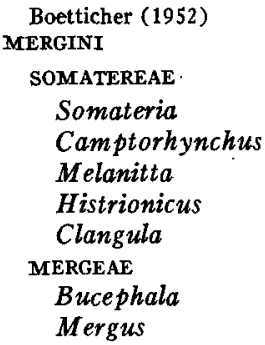

As part of a more general study on the behavior of the entire family Anatidae, based on the observation of 117 out of 143 living species of waterfowl at the Wildfowl Trust, Slimbridge, England, I have given some attention to this problem. I have been able to study in detail under wild conditions and/or in captivity 12 species of the sea ducks, including all the extant genera except Histrionicus. Courtship display has been observed in all 12 of these species, and copulatory behavior has been observed in 10 species. The behavior of these species will be reported on in detail at a later time, but a sum- 
mary of my findings on the sea ducks has a bearing on these proposed classifications and will be presented here.

Since male courtship display is extremely adaptive and subject to selective pressures for divergence as a species-specific signal under conditions of sympatry with related species, it is of unquestionable taxonomic value only within genera. It is of interest, however, that in all the sea ducks studied to date two comfort movements occur during male display which are clearly ritualized and constitute homologous displays throughout the whole group. These are, in Myres' (MS) terminology, the "upwards-stretch" and the "upwards-stretch with wing-flapping." In the eiders these displays are very frequent and clearly function to exhibit the dark under parts. In Somateria, at least, the "upwards-stretch with wing-flapping" when used as a display is markedly different from this behavior when performed as a simple comfort movement (see McKinney, in Delacour, 1959). Likewise in Polysticta the "upwards-stretch" movement used during display is recognizably different from the normal body shake and is remarkably similar to the "upwards-stretch" of Melanitta. The "upwards-stretch" is also frequently performed by displaying Old-squaws, goldeneyes, Buffleheads, and mergansers. In the Buffleheads, the "upwards-stretch with wing-flapping" is particularly ritualized and is a major male display. In the Anatini, Cairinini and Aythyini the nearest thing to an "upwards-stretch" is the "introductory shake" (Lorenz, 1951-1953), which is performed uniformly alike by nearly all species in these tribes, and it is distinctly different in form from the "upwards-stretch" of the sea ducks.

Female behavior patterns are particularly useful in assessing relationships among the higher taxonomic categories. One female display, called "inciting" by Lorenz (19511953 ) is highly conservative and occurs in all tribes of the Anatinae with the single possible exception of the stiff-tail group (Oxyurini). In the sea ducks this behavior takes several markedly different forms, but in all it is equivalent in function and is almost certainly homologous in origin. In the eiders "inciting" has a marked chin-lifting comnent, alternating with threatening movements and calls. In the scoters only the chinlifting component is present. "Inciting" has not yet been observed in the Harlequin or Old-squaw. In the goldeneyes there is no chin-lifting present, and the threatening movements are usually directed alternately to the two sides of the body ("jiving" of Myres, MS). In the Bufflehead the equivalent movement ("following" of Myres, MS) consists of rapid neck stretching and shortening, without the sideways threatening movements. In some of the mergansers "inciting" takes a curious form ("bobbing" of Hollom, 1937), in which the bill is primarily pointed downward rather than toward the side as the female energetically "leaps" forward through the water. In one species (Mergus merganser) this leaping component is present but there is also a distinct sideways pointing movement of the bill. The male response in all sea ducks, as well as in most other species of Anatinae, is the same, namely to swim ahead of the female while orienting the back of the head toward her (Johnsgard, 1960c). Of these types of "inciting," only that of the eiders is similar to "inciting" in females of other tribes, being most like that of the pochards (Aythyini).

All the sea ducks studied to date have similar pre-copulatory behavior patterns. The female assumes the receptive, or "prone," posture without mutual bathing or headpumping display and remains in this position for a period ranging from a few seconds (as in Old-squaw and some scoters) to several minutes (eiders, goldeneyes and mergansers). The only other tribe where such a soliciting posture of the females occurs is in some species of perching ducks (Cairina and Aix). Before mounting, the male usually performs various displays that may be the same as the courtship postures or, more often, include ritualized comfort movements such as stretching, preening, and drinking. Similar 
male pre-copulatory displays are found in a few perching ducks (Aix), and most if not all species of the pochard group perform mutual drinking and preening movements before the female allows the male to mount her.

During treading, males of several species of sea ducks vigorously flick their wings, producing a loud drumming sound which presumably has an auditory function. This has been observed in three genera (Melanitta, Bucephala and Mergus) only and is not known to occur in other tribes. In some sea ducks (Somateria, Bucephala, Mergus cucullatus) the male holds on to the female's nape for several seconds after copulation is completed, and the two birds "rotate" about a point. In these species the male "steams" rapidly away from the female after finally releasing her, turning his head mechanically from side to side. Similar rotary movements occur in some shelducks (Tadornini) and one perching duck (Callonetta="Anas" leucophrys), but they do not occur in the Anatini or Aythyini. Post-copulatory "steaming" with head-turning is not found in any other group.

Although flight-intention movements would appear to have only limited taxonomic significance, the various duck groups are relatively well distinguished by these signals. Lateral head-shaking is a flight intention movement of most species of Anatidae, but it is of interest that the sea ducks studied thus far utilize only this type of flight signal. It is performed in association with an alert posture characterized by an erect neck, slimmed plumage, and a slightly up-tilted bill. In the Cairinini lateral head-shaking is combined with "pointing" movements of the bill (Lorenz, 1951-1953), whereas in the

Table 1

Comparison of Characteristics of Sea Duck Genera and of Other Related Tribes

Consume animal food mainly

Nest in holes

Speculum nonmetallic

Mature 2 nd or 3 rd year

Downy young well marked

Tail long and broad

Female plumage disruptive

Tracheal bulla osseus

Trachea varies in diameter

Dive with wings open

"Upwards-stretch" male display

Female "inciting" display

Female prone posture

Precopulatory drinking ( $\delta$ )

Precopulatory "upwards-stretch"

Precopulatory preening

Copulatory wing-flick

Postcopulatory rotations

Postcopulatory "steaming"

Head-shake only pre-

flight signal

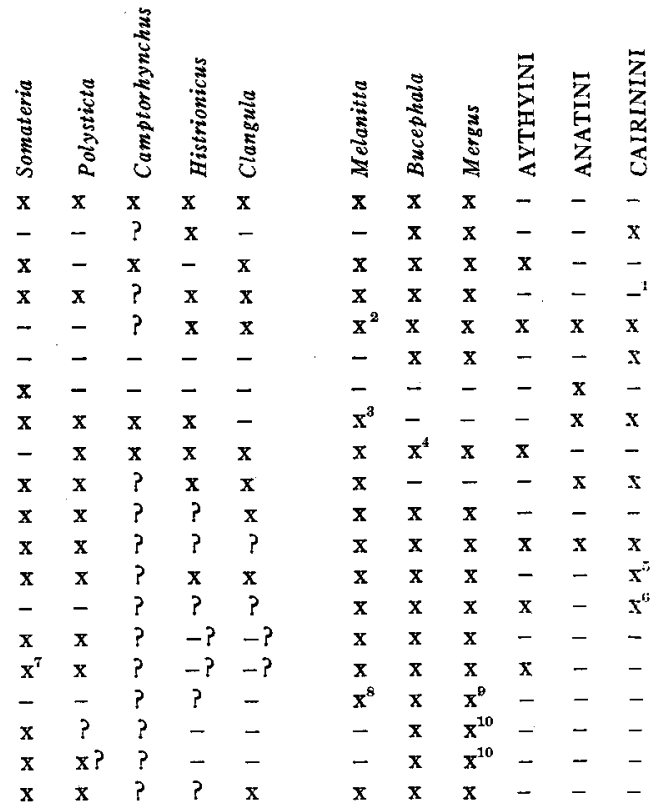

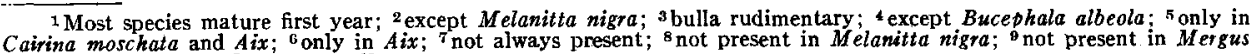
Cairina moschata and Aix; ' only in $A i x$

merganser; 10 only in Mergus cucullatus.
"" $\mathrm{x"}$ indicates presence of characteristic; dash indicates absence of characteristic. 
Anatini faster neck-jerking movements occur along with lateral head-shaking (McKinney, 1953). In the Aythyini lateral head-shaking is accompanied by rapid and repeated chin-lifting movements.

These points concerning behavior are summarized in table 1 , which also includes characteristics used by Delacour and Mayr (1945) in defining the group, as well as tracheal and diving characteristics utilized by Humphrey (MS) in his studies. Although numerous gaps still remain in our knowledge of the behavior of the sea ducks, enough information is at hand to make some objective comparisons among the genera of sea ducks and between the sea ducks and their possible closest relatives. By totaling the number of points in which various species or groups agree (20 possible) and disregarding those where the information is doubtful or absent, an index to similarity and probable phyletic affinities can be obtained. Such a tabulation is presented in table 2. From this table it can be observed that the genus Somateria agrees with the Anatini in nine out of 20 points (45 per cent), and Polysticta agrees with the Anatini in eight out of 18 points (44 per cent). Somateria agrees with the other sea ducks, excluding Polysticta, in 55 out of 95 points ( 58 per cent). Polysticta agrees with the other sea ducks (exclud-

Table 2

Table Illustrating Degrees of Similarity Among Genera of Sea Ducks and Other Related Tribes ${ }^{1}$

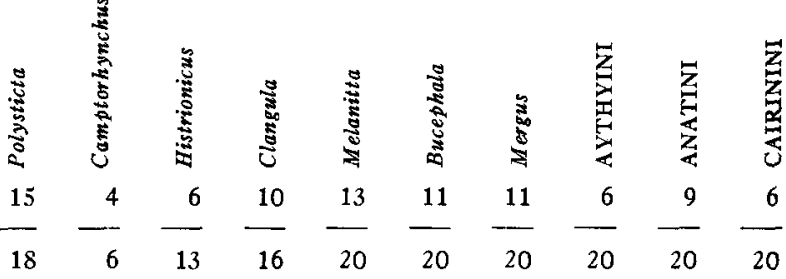

$$
\begin{aligned}
& \begin{array}{rrrrrrrrrrr}
\text { Polystica } & \frac{5}{6} & -\frac{1}{11} & \frac{10}{13} & \frac{13}{18} & \frac{10}{18} & \frac{10}{18} & \frac{7}{18} & \frac{8}{18} & \frac{7}{18}
\end{array} \\
& \begin{array}{lrrrrrrrrrrr}
\text { Camptorhynchus } \quad \frac{5}{6} & -\frac{5}{6} & -\frac{4}{6} & -\frac{4}{6} & -\frac{4}{6} & -\frac{2}{6} & \frac{2}{6} & \frac{2}{6}
\end{array} \\
& \text { Histrionicus } \quad \frac{10}{13} \quad \frac{11}{13} \quad \frac{7}{13} \quad \frac{7}{13} \quad \frac{6}{13} \quad \frac{7}{13} \quad \frac{9}{13} \\
& \begin{array}{lllllll}
\text { Clangula } \quad \frac{14}{16} & \frac{10}{16} & \frac{10}{16} & -\frac{10}{16} & \frac{7}{16} & \frac{7}{16}
\end{array} \\
& \text { Melanitia } \frac{14}{20}, \frac{14}{20} \quad \frac{11}{20} \frac{8}{20} \frac{9}{20} \\
& \text { Bucephala } \frac{20}{20} \quad \frac{9}{20} \quad \frac{2}{20} \frac{7}{20} \\
& \text { Mergus } \quad \frac{9}{20} \quad \frac{2}{20} \frac{7}{20}
\end{aligned}
$$

\footnotetext{
1 Ratios were calculated from information presented in table 1.
} 
ing Somateria) in 57 out of 84 points ( 68 per cent). This indicates that the eiders have their closest relationships with the other sea ducks rather than with the Anatini. Taking the sea ducks as a group, including the eiders, it is of interest to compare their degrees of similarity to the other tribes. Out of a total of 133 points, the sea ducks agree with the Aythyini and Cairinini in 62 points ( 47 per cent) and 54 points ( 41 per cent), respectively, and with the Anatini in 45 points (34 per cent). This would indicate that the sea ducks' closest relatives are not the Anatini but rather the Aythyini. Since the Anatini and Aythyini are clearly very closely related tribes, the sea ducks may have developed from very early Aythyini-like forms which still exhibited some of the characteristics (trachea, female plumage) of dabbling ducks.

\section{ACKNOWLEDGMENTS}

This paper was written while the author was studying at the Wildfowl Trust on a National Science Foundation postdoctoral fellowship. I would like to express my appreciation to the Wildfowl Trust for their wonderful hospitality, and I particularly wish to thank Peter Scott for his stimulating ideas and helpful observations.

\section{CONCLUSIONS}

The eiders, although not altogether typical sea ducks, certainly show their closest affinities with that group, and the presence of intermediate forms represented by the Labrador Duck and perhaps also the Harlequin Duck makes it unwise, in my judgment, to divide the sea ducks into two tribes. Of the classifications available, that of Delacour and Mayr (1945) seems to me to be closest to reality, except that the Steller Eider undoubtedly warrants generic distinction from the typical eiders; in courtship and precopulatory behavior it exhibits closer affinities to the other sea ducks than does Somateria. I would propose the following sequence of genera: Somateria, Polysticta, Camptorhynchus, Histrionicus, Clangula, Melanitta, Bucephala, Mergus. Since these genera are all so well-marked I cannot accept Myres' (MS) opinion that the Bufflehead should be placed in a separate genus from the goldeneyes, although it does appear to provide a link between the goldeneyes and scoters.

\section{IITERATURE CITED}

American Ornithologists' Union

1957. Check-list of North American birds. Fifth ed. (published by the Union, Baltimore, Md.).

Boetticher, $\mathbf{H}$. von

1952. Gänse- und Entenvögel aus aller Welt. Die Neue Brehm-Bücherei, Heft 73.

Cottam, C.

1939. Food habits of North American diving ducks. U.S. Dept. Agr., Tech. Bull. 643.

Delacour, J.

1959. The waterfowl of the world. Vol. 3 (Country Life Limited, London).

Delacour, J., and Mayr, E.

1945. The family Anatidae. Wilson Bull., 57:3-55.

Hollom, P. A. D.

1937. Observations on the courtship and mating of the Smew. Brit. Birds, 31:106-111.

Humphrey, P.S.

1958. Classification and systematic position of the eiders. Condor, 60:129-135.

Lorenz, $\mathrm{K}$.

1951-1953. Comparative studies on the behaviour of the Anatinae. Avic. Mag., 57:157-182; $58: 8-17,61-72,86-94,172-184 ; 59: 24-34,80-91$. 
Johnsgard, P. A.

1960a. Hybridization in the Anatidae and its taxonomic implications. Condor, 62:25-33.

1960b. Comparative behaviour of the Anatidae and its evolutionary implications. 11th Annual Report, Wildfowl Trust:31-45.

1960c. Pair formation mechanisms in Anas (Anatidae) and related genera. Ibis, 102:616-618.

1961. The sexual behavior and systematic position of the hooded merganser (Mergus cucullatus).

Kagelmann, G. Wilson Bull. (in press).

1951. Betrachtungen zur Stammesgeschichte der Anatiden. Schrift. des Naturwiss. Verein für Schleswig-Holstein, 25:18-28.

Myres, M. T.

1959. Display behavior of bufflehead, scoters and goldeneyes at copulation. Wilson Bull., $71: 159-168$.

Peters, J. L.

1931. Check-list of birds of the world. Vol. I (Harvard Univ. Press, Cambridge).

Wilson, A

1829. American ornithology. Vol. 3 (Collins and Co., New York).

The Wildfowl Trust, Slimbridge, Gloucester, England, June 18, 1960. 